\title{
10 Some unresolved problems
}

To me it is far more pleasant to agree than to differ; but it is impossible that one who has any regard for truth can long avoid protesting against doctrines which seem to him to be erroneous. There is ever a tendency of the most hurtful kind to allow opinions to crystallize into creeds ... A despotic calm is usually the triumph of error. In the republic of the sciences sedition and even anarchy are beneficial in the long run to the greatest happiness of the greatest number.

W. Stanley Jevons (1970, p. 260)

Scientific progress is a process of creative destruction. What is destroyed is the intellectual capital of other scientists whose resistance to accepting new contributions is not only understandable, but desirable; it is only by overcoming this resistance that the few genuine contributions can be separated from the more numerous invalid proposals.

Melvin W. Reder (1982, p. 20)

At the beginning of this book, we suggested that what separates schools in science is the questions posed, not the answers given. Certainly in the history of economics, major innovations have occurred when theorists observing the same phenomena asked new questions about it. And these innovations have been opposed precisely because different questions were being asked. In the eighteenth century, students of government sought to devise policies that would achieve a pre-ordained social pattern and lead to an increase in national wealth. Adam Smith altered the nature of the inquiry by asking a different question. He speculated on how a nation of autonomous individuals, each seeking to increase his own wealth and well-being, could produce an overall order that was no part of anyone's intention. The answers to this question spawned what we now recognize as economic science.

A century later, Ricardianism had transformed economics into an arid set of laws of distribution and production, conjoined with a dubious population theory. Jevons, Menger and, to a lesser extent, Walras posed a new question: What governs the choices of consumers? The resulting neoclassical analysis transformed economics into the science of choice. It also transformed economics from a predominantly macro- into a predominantly microanalytic discipline. 
In this century, Keynes changed economics by inquiring into the determination of aggregate demand and national income. In a sense, economics had now come full circle back to macroanalysis and the study of distributional rather than allocational questions. The subsequent dilution of Keynesianism in the neoclassical synthesis is well known but does not change our interpretation of the Keynesian message.

Subjectivists do not perform constrained maximization problems differently than neoclassical theorists. Nor are subjectivists privy to a special mathematics that yields different solutions to familiar equations. Subjectivists do, however, ask different questions. To relate our philosophy of science to our concise history of economics, subjectivists try consistently to analyze economic phenomena within the framework first sketched out by Menger in the last century. This involves, inter alia, a focus on the goals and plans of individuals, not on the objects or instruments of these plans; the reconstruction of observed phenomena in terms of individual choices; and the analysis of overall outcomes as the unintended results of individual interactions.

We have attempted to steer a course, as it were, between Charybdis and Scylla. On the one hand, we have sought to avoid unnecessary controversy. We are certainly aware that, within the neoclassical edifice, many of the individual points that we have made in this book are recognized and incorporated in the work of at least some major figures. Indeed, wherever possible we have cited the orthodox literature to emphasize points of convergence or, alternatively, the subjectivist elements in neoclassical economics. Where we are critical, our purpose in citing specific individuals is not to foment controversy but to be precise in our criticism. In every instance, we have attempted to cite an author who is representative of the orthodox position on a particular point.

On the other hand, we have been cognizant of the necessity of clearly stating the differences that do exist between subjectivists and their neoclassical brethren. It should not be surprising if there were substantial overlap between Austrian or subjectivist economics and neoclassical orthodoxy. The Austrians were one of the three founding schools of modern economics; and, in fact, there are more Austrian elements in neoclassical economics than are recognized in textbooks (including, via Lord Robbins, the very conception of economics as the study of the allocation of scarce means among competing ends). The reader may at times wonder why we have not emphasized this overlap more. The simple reason is that the subjectivist analysis would then have been obscured. Our purpose in writing this book was to restate and advance subjectivist economics. This goal would scarcely have been promoted by presenting an exhaustive list of neoclassical propositions with which we agree.

There is a "sponginess" to neoclassical economics that enables it to absorb divergent elements around it without ever emphasizing their main points. These fringe ideas become footnotes to which theorists can refer as evidence that they have taken the ideas into account. For instance, Keynes' liquidity 
preference concept is incorporated in neoclassical economics as an interestelastic demand for money. The idea has been formally incorporated, yet Keynes' main point has been lost: the instability of liquidity preference. Nor are the effects of an unstable liquidity preference on interest rates and capital markets adequately treated in orthodox analysis. In terms of our own ideas, we have chosen to compare them to the dominant themes of neoclassical economics and not to unrepresentative footnote presentations.

We have also attempted to strike a balance between, on the one hand, presenting theoretical and methodological abstractions and, on the other hand, offering examples or applications. We did not wish to overwhelm the reader with too much of the former, or to confuse him with too much of the latter. If, however, we were to characterize the subjectivist literature generally, we would have to admit that it has been relatively long on methodological prescriptions and short on applications. It is time to do the difficult work of applying subjectivist ideas to actual problems. We are aware that most of our applications involve only a sketchy analysis of a particular problem. In almost every case, more work needs to be done. We believe, however, that the time is ripe for applying subjectivist insights to current economic problems. Accordingly, we outline here some areas where we think the returns would be particularly high.

First, we would mention the whole area of law and economics. We do so not only because we have each written in this area, but because it is a field that virtually demands the theoretical-institutional approach advocated by subjectivists. If any area involves a blending of theoretical and institutional analysis, it is law and economics. Nowhere else is an institutionless analysis less fruitful and more destructive. For instance, a good bit of ink has been spilled on the question of the efficiency of common law. This view, first of all, treats an undesigned order as if it were the creation of individuals; and, second, it puts the theoretical cart before the horse. What is efficient depends on the institutional environment. One can inquire whether a particular institution is consistent with a whole set of institutions (as when one analyzes the consistency of a common law doctrine with all others). It is quite meaningless, however, to ask whether an entire set of institutions - like the property rights structure - is efficient. This question treats as "givens" conditions that change mutatis mutandis as property rights evolve (Rizzo, 1980b; O’Driscoll, 1980). Of course, having made this point, we have only opened up a research program, not completed one. Needless to say, an important aspect of that program involves a theory of these institutions that does not treat them as the outcome of a collective constrained-maximization problem. The next item on our subjectivist research agenda is a suggestion for a start in this direction.

The analysis of money as an evolved social institution is a quintessential subjectivist topic. Viewing money as the unintended outcome of a market process involves thinking about money in a fundamentally different way (Frankel, 1977). Money then becomes not something that individuals can 
shape or control, but an institution or order to which they must accommodate themselves. In this process of accommodation, individuals will inadvertently affect the monetary order. The resulting monetary "innovations" will not, however, be changes that individuals have deliberately adopted: rather, these changes will represent evolutionary adaptation. Even when dramatic choices are made, as when a gold standard is substituted for a fiat money system, or fixed exchange rates are substituted for flexible exchange rates, policy-makers have not created new monetary institutions so much as they have moved the country from one given environment or regime to another. Policy-makers do not necessarily have a great deal of explicit control over the characteristics of either environment. They may surely take actions that affect their environment, but this does not imply that they can control the outcome. If we may suggest an analogy, we each have options with respect to which kind of climate we live in. We choose by moving from one climate to another, however, not by altering the climate of the area in which we presently live. The sum total of individual actions may affect the climatic environment, but even collective action will not enable individuals to effect a desired outcome.

The monetary approach suggested here has policy implications, of which two can be mentioned. The first concerns the nature of monetary rules. Every monetary system has or can be described by rules, including rules governing the growth of the supply of money. If a monetary system is an evolved economic order, then it is difficult to imagine how these rules could be externally imposed or chosen exogenously. The rules themselves, including the money growth rules, must be the product of an evolutionary process - a process of economic adaptation. Macroeconomic planning for a fixed rate of growth of the money supply has all the allure of microeconomic planning - and all the pitfalls, if recent history is any guide.

The second implication is more specific, though it is related to the first one. If the monetary institutions and money itself are part of the market system, then it is difficult to imagine how the quantity of money could be exogenous or independent of individual choices. Empirical evidence aside, there are strong a priori reasons to suspect the endogeneity of the money supply. Of course, empirically we may recognize that monetary questions have historically become political questions, and that political intervention leads to exogenous influences on the quantity or rate of growth of the money supply. This recognition puts the question of the exogeneity of the money supply in quite a different light, however, than that produced by, say, monetarist analysis. In the evolutionary view, money is a market institution and its supply is endogenously determined. There may be exogenous factors, as there are exogenous factors like fortuitous inventions in economic growth. An unexpected discovery of new sources of base money would be an example of an exogenous monetary change. For the supply of money to be strictly exogenous, however, it must be transformed from an economic or market institution into one subject to rigid political control. And market forces will constantly be at work offsetting the effects of these controls. 
We think that an evolutionary approach to money has more explanatory power for analyzing recent financial market innovations, including the multiplication of close money substitutes (if not money themselves), than a positive theory of exogenous money determination.

Finally, we turn once again to the topic of competition. Economists analyzing competition as a process need to develop a theory of nonprice information structures. Neoclassical formulations rely almost exclusively on prices to convey information. This is untenable as soon as one incorporates real time and expectations in the analysis. Spot-price movements no longer convey unambiguous signals. Even were futures markets to be "complete," the passage of time would upset any temporary intertemporal equilibrium. Not only do producers require information about trade-offs, they need to know how other producers will react to these prices. No matter how rich the array of futures markets producers confront Keynes' beauty contest problem.

Entrepreneurs are not, of course, paralyzed by this informational void. Their ability to plan in a tolerably stable environment indicates the existence of other, nonprice, sources of information. There must be market institutions and rules of thumb that "fill in" some of the information not provided by prices. This realization requires, however, that we rethink our attitude toward familiar institutions and practices. For some of the required information will be about product characteristics, production plans, and even prices charged by competitors. Competition may, then, depend on the existence of institutions and practices presently regarded as non-competitive or anti-competitive.

In Chapter 5 we discussed endogenous uncertainty in the guise of Keynes' beauty contest and the Holmes-Moriarty story. We saw there that, as long as independent decision-making remains independent, the search for more knowledge does not reduce uncertainty. It merely heightens the level of guessing and counterguessing. In this sense, then, endogenous uncertainty is ineradicable. On the other hand, as we have previously intimated, endogenous uncertainty can be reduced or eliminated if actors (agree to) follow "arbitrary conventions." Independent firms, for example, face endogenous uncertainty in the form of trying to guess the price decisions of their rivals. In "oligopolistic" markets, the price that any given firm should charge will depend, in part, on the prices that he expects other firms to charge. Their decisions will in turn depend on what he is expected to decide. Thus, the expected price distributions faced by firms are endogenous; that is, they arise from the very operation of the market process. One "arbitrary convention" or institution that can reduce this form of uncertainty is the exchange of reliable price information among the rival firms.

Firms are subject to both exogenous and endogenous uncertainty. While exogenous risk may be transformed, by definition nothing can be done to eliminate it. Endogenous uncertainty arises from the very operation of the market. At least in principle, some actions can be taken to lessen this type of uncertainty. Consider uncertainty about what price to charge. At any given moment, firms observe a distribution of prices charged by their competitors, a 


\section{The economics of time and ignorance}

distribution that need by no means be normal. Firm owners are aware, moreover, that they do not have complete information about prices. The variance of prices reflects, inter alia, temporary cost advantages, special discounting and product differentiation.

Each firm owner desires information that will improve his planning ability. This would include information about the mean and variance of the price distribution, product characteristics, amounts sold at these prices, etc. All of this information is either given or superfluous in perfectly competitive models, but is available only at some cost in competitive markets. Though he would never describe it in this way, the entrepreneur is seeking information about equilibrium conditions in his market. Though he may have quite different uses in mind for this information, a competitive firm owner requires much of the same information needed by a cartel.

By reducing price uncertainty, information-sharing arrangements may reduce the variance of prices. If firms are risk-averse, this may also reduce the mean of the price distribution. This latter point is emphasized in Dewey (1979), while Rizzo (1984) presents the more general argument.

None of this sanctions other aspects of collusive arrangements, especially not legal barriers to entry. Indeed, the existence or absence of legal blockages to competition would surely be crucial in ascertaining empirically whether an exchange of information were facilitating collusion or abetting competition.

We are not arguing that the exchange of price information would be generally characteristic of competitive industries, though some of it probably occurs in every industry (including among economists). We are suggesting, however, that competitive markets will generally rely on institutions and practices to generate information assumed in neoclassical analysis to be given by price signals alone. Sharing of price information may be one of these practices, which may also be institutionalized. A theory leaving no room for these nonprice sources of information is an impoverished - indeed, a biased - analysis of competition.

In conclusion, we have attempted in this book to offer a sample of research topics whose development would especially benefit from a consistent application of subjectivist economics. This sample is certainly not meant to be exhaustive, reflecting, as it does, the constraints both of space and of the authors' own interests. We will count this book a success if readers begin adding their own items to the research agenda. 


\section{Bibliography}

Ackerman, R. (1976) The Philosophy of Karl Popper Amherst, Mass.: University of Massachusetts Press.

Alchian, A. A. and Demsetz, H. (1972) "Production, Information Costs and Economic Organization." American Economic Review 62: 777-95. Reprinted in Economic Forces at Work: Selected Works by Armen A. Alchian Indianapolis: Liberty Press, 1977.

Allais, M. (1966) "A Restatement of the Quantity Theory of Money." American Economic Review 56: 1123-57.

Allen, P. M. (1994) "Evolutionary Complex Systems: Models of Technology Change." In L. Leydesdorff and P. van der Besselaar (eds.) Evolutionary Economics and Chaos Theory New York: St. Martin's Press.

Arrow, K. J. (1959) "Toward a Theory of Price Adjustment." In M. Abramovitz and B. F. Haley (eds.) The Allocation of Economic Resources Stanford, Cal.: Stanford University Press.

Arrow, K. J. (1968) "Economic Equilibrium." In D. L. Sills (ed.) International Encyclopedia of the Social Sciences 4: 376-88. London and New York: Macmillan and Free Press.

Arrow, K. J. (1974) The Limits of Organization New York: W. W. Norton \& Company.

Arrow, K. J. and Hahn, F. H. (1971) General Competitive Analysis San Francisco: Holden-Day.

Arthur, B. (1990) "Positive Feedbacks in the Economy" Scientific American 262: 92-9.

Barreto, H. (1989) The Entrepreneur in Microeconomic Theory: Disappearance and Explanation London: Routledge.

Baumol, W. J. (1965) Economic Theory and Operations Analysis (2nd edn) Englewood Cliffs, NJ: Prentice-Hall.

Baumol, W. J. (1972) "On Taxation and the Control of Externalities." American Economic Review 62: 307-22.

Bausor, R. (1981) "Time and the Structure of Economic Analysis." Unpublished paper, University of Massachusetts at Amherst.

Becker, G. S. (1965) "A Theory of the Allocation of Time." Economic Journal 75: 493-517.

Becker, G. S. (1971) Economic Theory New York: Alfred A. Knopf.

Becker, G. S. (1976a) The Economic Approach to Human Behavior Chicago: University of Chicago Press.

Becker, G. S. (1976b) "Toward a More General Theory of Regulation: Comment." Journal of Law and Economics 19: 211-40. 
Begg, D. K. H. (1982) The Rational Expectations Revolution in Macroeconomics: Theories and Evidence Baltimore: Johns Hopkins University Press.

Berger, P. L. and Luckmann, T. (1966) The Social Construction of Reality New York: Anchor Books, Doubleday \& Co.

Bergson, H. (1910) Time and Free Will: An Essay on the Immediate Data of Consciousness Trans. F. L. Pogson. London: George \& Allen Unwin.

Bergson, H. (1911) Creative Evolution New York: Henry Holt.

Bergson, H. (1920) Mind-Energy New York: Henry Holt.

Bergson, H. (1946) "The Possible and the Real." In The Creative Mind Trans. Mabel L. Andison. Westport, Conn.: Greenwood Press.

Birner, J. and van Zijp, R. (eds.) (1994) Hayek, Coordination, and Evolution London: Routledge.

Blackstone, W. (1803) Commentaries on the Laws of England Book 4, London: T. Codell and W. Davies.

Boettke, P. J. (1990a) "Institutions and Individuals: A Review of Geoffrey Hodgson, Economics and Institutions." Critical Review 4: 10-26.

Boettke, P. J. (1990b) "Interpretive Reasoning and the Study of Social Life." Methodus: Bulletin of the International Network for Economic Method 2: 35-45.

Boettke, P. J. (1990c) The Political Economy of Soviet Socialism: The Formative Years, 1918-1928 Boston: Kluwer Academic Press.

Boettke, P. J. (1993) Why Perestroika Failed: The Politics and Economics of Socialist Transformation London: Routledge.

Boettke, P. J. (1994) "The Reform Trap in Politics and Economics in the Former Communist Economies." Journal des Economistes et des Etudes Humaines 5: 267-93.

Boettke, P. J., Horwitz, S. and Prychitko, D. L. (1994) "Beyond Equilibrium Economics: Reflections on the Uniqueness of the Austrian Tradition." In P. J. Boettke and D. L. Prychitko (eds.) The Market Process: Essays in Contemporary Austrian Economics Aldershot, England: Edward Elgar.

Böhm-Bawerk, E. v. (1959 [1889]) Capital and Interest (3 vols) Trans. G. D. Huncke and H. F. Sennholz. South Holland, Ill.: Libertarian Press.

Bork, R. H. (1978) The Antitrust Paradox: A Policy at War with Itself New York: Basic Books.

Boulding, K. E. (1966) "The Economics of Knowledge and the Knowledge of Economics." American Economic Review, Papers and Proceedings 56: 1-13.

Briggs, J. A. (1981) “Fly Me, I'm Little.” Forbes 27 April: 112-18.

Buchanan, J. M. (1969) Cost and Choice Chicago: Markham.

Buchanan, J. M. (1979) "Natural and Artifactual Man.” In What Should Economists Do? Indianapolis: Liberty Press.

Buchanan, J. M. (1982a) "The Domain of Subjective Economics: Between Predictive Science and Moral Philosophy." In I. M. Kirzner (ed.) Method, Process, and Austrian Economics: Essays in Honor of Ludwig von Mises Lexington, Mass.: Lexington Books, D. C. Heath \& Co.

Buchanan, J. M. (1982b) “Order Defined in the Process of its Emergence." Literature of Liberty 5: 5.

Buchanan, J. M. (1986) "Order Defined in the Process of Its Emergence." In Liberty, Market and State: Political Economy in the 1980s New York: New York University Press. 
Burczak, T. A. (1994) "The Postmodern Moments of F. A. Hayek's Economics." Economics and Philosophy 10: 31-58.

Butos, W. and Koppl, R. (1993) "Hayekian Expectations: Theory and Empirical Applications." Constitutional Political Economy 4: 303-29.

Caldwell, B. J. (1982) Beyond Positivism: Economic Methodology in the Twentieth Century London: George Allen \& Unwin.

Capek, M. (1961) The Philosophical Impact of Contemporary Physics Princeton: D. Van Nostrand.

Capek, M. (1971) Bergson and Modern Physics Boston Studies in the Philosophy of Science, vol. VIII, Dordrecht, Holland: D. Reidel.

Cassel, G. (1903) The Nature and Necessity of Interest London: Macmillan.

Choi, Y. B. (1993) Paradigms and Conventions Ann Arbor: University of Michigan Press.

Clair, R. T. and O’Driscoll, G. P. Jr. (1993) “Learning from One Another: The U.S. and European Banking Experience." Journal of Multinational Management 2: 33-52.

Clower, R. W. (1965) "The Keynesian Counter-Revolution: A Theoretical Appraisal." In F. H. Hahn and F. P. R. Brechling (eds.) The Theory of Interest Rates London: Macmillan. Also in R. W. Clower (ed.) Monetary Theory Harmondsworth, Middlesex: Penguin Books, 1969.

Coase, R. H. (1937) "The Nature of the Firm.” Economica n.s. 4: 386-405.

Coase, R. H. (1960) "The Problem of Social Cost." Journal of Law and Economics 3: $1-40$.

Coddington, A. (1975) "Creaking Semaphore and Beyond: A Consideration of Shackle's 'Epistemics and Economics.' " British Journal for the Philosophy of Science 26: $151-63$.

Cohen, L. J. (1977) The Probable and the Provable Oxford: Clarendon Press.

Colonna, M. and Hagemann, H. (eds.) (1994a) Money and Business Cycles: The Economics of F. A. Hayek vol. 1, Aldershot, England: Edward Elgar.

Colonna, M. and Hagemann, H. (eds.) (1994b) Capitalism, Socialism and Knowledge: The Economics of F. A. Hayek vol. 2, Aldershot, England: Edward Elgar.

Comte, A. (1988 [1855]) Introduction to Positive Philosophy Trans. F. Ferre. Indianapolis, IN: Hackett.

Cowan, R. and Rizzo, M. (1995) "The Causal-Genetic Tradition and Economic Theory." Unpublished Manuscript at the University of Western Ontario and New York University.

Cowen, T. and Kroszner, R. (1994) Explorations in the New Monetary Economics Oxford: Basil Blackwell.

Dahrendorf, R. (1968) Essays in the Theory of Society Stanford: Stanford University Press.

Davidson, P. (1981) "Post Keynesian Economics: Solving the Crises in Economic Theory." The Public Interest, Special Issue: 123-38.

Demsetz, H. (1969) "Information and Efficiency: Another Viewpoint." Journal of Law and Economics 12: 1-22.

Demsetz, H. (1982) "Barriers to Entry." American Economic Review 72: 45-57.

Denzau, A. T. and North, D. C. (1994) "Shared Mental Models: Ideologies and Institutions." Kyklos 47: 3-31.

Dewey, D. (1979) "Information, Entry and Welfare: The Case for Collusion." American Economic Review 69: 587-94. 
Dolan, E. G. (ed.) (1976) The Foundations of Modern Austrian Economics Kansas City: Sheed \& Ward.

Doty, L. (1977) "New Pacts Reflect Commuter Success." Aviation Week \& Space Technology 4 April: 38.

Epstein, R. A. (1982) "Private Property and the Public Domain: The Case of Antitrust." In J. R. Pennock and J. W. Chapman (eds.) Ethics, Economics and the Law New York: Nomos, New York University Press.

Faber, M. (ed.) (1986) Studies in Austrian Capital Theory, Investment and Time Berlin: Springer-Verlag.

Fetter, F. A. (1977) Capital, Interest, and Rent: Essays in the Theory of Distribution (ed.) M. N. Rothbard Kansas City: Sheed Andrews \& McMeel.

Feyerabend, P. K. (1975) Against Method London: Verso.

Fisher, F. M. (1983) Disequilibrium Foundations of Equilibrium Economics Cambridge: Cambridge University Press.

Frankel, S. H. (1977) Money: Two Philosophies Oxford: Basil Blackwell.

Friedman, M. (1953) "The Methodology of Positive Economics." In Essays in Positive Economics Chicago: University of Chicago Press.

Friedman, M. (1977) "The Monetarist Controversy: Discussions by Milton Friedman and Franco Modigliani." Federal Reserve Bank of San Francisco Economic Review Supplement.

Frydman, R. (1982) "Towards an Understanding of Market Processes: Individual Expectations, Learning, and Convergence to Rational Expectations Equilibrium.” American Economic Review 72: 652-68.

Frydman, R. and Phelps, E. S. (eds.) (1983) Individual Forecasting and Aggregate Outcomes: "Rational Expectations" Examined New York: Cambridge University Press.

Frydman, R., O’Driscoll, G. P. Jr. and Schotter, A. (1982) "Rational Expectations of Government Policy: An Application of Newcomb's Problem.” Southern Economic Journal 49: 311-19.

Gallaway, L. and Vedder, R. (1987) "Wages, Prices and Employment: Von Mises and the Progressives." Review of Austrian Economics 2: 33-80.

Garrison, R. W. (1978) "Austrian Macroeconomics: A Diagrammatical Exposition." In L. M. Spadaro (ed.) New Directions in Austrian Economics Kansas City: Sheed, Andrews \& McMeel.

Garrison, R. W. (1979) "Comment: Waiting in Vienna.” In M. J. Rizzo (ed.) Time, Uncertainty, and Disequilibrium Lexington, Mass.: Lexington Books, D. C. Heath \& Co.

Garrison, R. W. (1984) "Time and Money: The Universals of Macroeconomic Theorizing." Journal of Macroeconomics 6(2): 197-213.

Gjertsen, D. (1989) Science and Philosophy: Past and Present London: Penguin.

Gordon, D. F. and Hynes, A. (1970) "On the Theory of Price Dynamics." In E. S. Phelps (ed.) Macroeconomic Foundations of Employment and Inflation Theory New York: W. W. Norton.

Grossman, S. J. (1976) "On the Efficiency of Competitive Stock Markets Where Traders Have Diverse Information.” Journal of Finance 31: 573-85.

Grossman, S. J. (1977) "The Existence of Futures Markets, Noisy Rational Expectations and Informational Externalities." Review of Economic Studies 44: 431-49.

Grossman, S. J. and Stiglitz, J. E. (1976) "Information and Competitive Price Systems." American Economic Review 66: 246-53. 
Hahn, F. H. (1952) “Expectations and Equilibrium.” Economic Journal 62: 802-19.

Hahn, F. H. (1973) On the Notion of Equilibrium in Economics Cambridge University Inaugural Lecture. Cambridge: Cambridge University Press.

Hahn, F. H. (1980) “General Equilibrium Theory.” The Public Interest, Special Issue: 123-38.

Hall, R. E. (1982) "The Government and the Monetary Unit." NBER Working Paper no. 159 Stanford: Stanford University Press.

Harcourt, G. C. and Laing, N. F. (eds.) (1971) Capital and Interest Harmondsworth, Middlesex: Penguin Books.

Harper, D. (1994) "A New Approach to Modelling Endogenous Learning Processes in Economic Theory." In Peter Boettke and Mario Rizzo (eds.) Advances in Austrian Economics, vol. 1 Greenwich, CT: JAI Press.

Harper, D. (1996) Entrepreneurship and the Market Process: An Inquiry into the Growth of Knowledge London and New York: Routledge.

Hausman, D. M. (1981) Capital, Profits, and Prices New York: Columbia University Press.

Hayek, F. A. (1932) "A Note on the Development of the Doctrine of 'Forced Savings." Quarterly Journal of Economics 47: 123-33. Reprinted in Profits, Interest and Investment; and Other Essays on the Theory of Industrial Fluctuations London: George Routledge \& Sons, 1939. This volume reprinted in Clifton, NJ by Augustus M. Kelley, 1975.

Hayek, F. A. (1935a) "The Nature and History of the Problem.” In F. A. Hayek (ed.) Collectivist Economic Planning: Critical Studies on the Possibilities of Socialism London: Routledge \& Kegan Paul. This volume reprinted in Clifton, NJ by Augustus M. Kelly, 1975. This essay also appears in Individualism and Economic Order Chicago: University of Chicago Press, 1948.

Hayek, F. A. (1935b) “The Present State of the Debate.” In F. A. Hayek (ed.) Collectivist Economic Planning: Critical Studies on the Possibilities of Socialism London: Routledge \& Kegan Paul. This volume reprinted in Clifton, NJ by Augustus M. Kelly, 1975. This essay also appears in Individualism and Economic Order Chicago: University of Chicago Press, 1948.

Hayek, F. A. (1937a) "Economics and Knowledge." Economica n.s. 4: 33-54. Reprinted in Individualism and Economic Order Chicago: University of Chicago Press, 1948.

Hayek, F. A. (1937b) "Investment That Raises the Demand for Capital." Review of Economic Statistics 19: 174-7. Reprinted in Profits, Interest and Investment; and Other Essays on the Theory of Industrial Fluctuations London: George Routledge \& Sons, 1939. This volume reprinted in Clifton, NJ by Augustus M. Kelley, 1975.

Hayek, F. A. (1939) "Price Expectations, Monetary Disturbances and Malinvestment." In Profits, Interest and Investment; and Other Essays on the Theory of Industrial Fluctuations London: George Routledge \& Sons. This volume reprinted in Clifton, NJ by Augustus M. Kelley, 1975.

Hayek, F. A. (1940) "Socialist Calculation: The Competitive 'Solution."' Economica n.s. 7: 125-49. Reprinted in Individualism and Economic Order Chicago: University of Chicago Press, 1948.

Hayek, F. A. (1941) The Pure Theory of Capital Chicago: University of Chicago Press.

Hayek, F. A. (1944) The Road to Serfdom Chicago: University of Chicago Press. 
Hayek, F. A. (1945) "The Use of Knowledge in Society." American Economic Review 35: 519-30. Reprinted in Individualism and Economic Order Chicago: University of Chicago Press, 1948.

Hayek, F. A. (1948a) "The Meaning of Competition." In Individualism and Economic Order Chicago: University of Chicago Press.

Hayek, F. A (1948b) "The Use of Knowledge in Society." In Individualism and Economic Order Chicago: University of Chicago Press.

Hayek, F. A. (1955) The Counter-Revolution of Science Glencoe, Ill.: Free Press.

Hayek, F. A. (1965) "Kinds of Rationalism." The Economic Studies Quarterly (Tokyo) vol. 15, no. 3. Reprinted in Studies in Philosophy, Politics and Economics Chicago: University of Chicago Press, 1967.

Hayek, F. A. (1966 [1933]) Monetary Theory and the Trade Cycle New York: Augustus M. Kelley.

Hayek, F. A. (1967a [1935]) Prices and Production (2nd edn) New York: Augustus M. Kelly.

Hayek, F. A. (1967b) "Degrees of Explanation." In Studies in Philosophy, Politics and Economics Chicago: University of Chicago Press.

Hayek, F. A. (1967c) "The Theory of Complex Phenomena.” In Studies in Philosophy, Politics and Economics Chicago: University of Chicago Press.

Hayek, F. A. (1969) "Three Elucidations of the Ricardo Effect." Journal of Political Economy 77: 274-85. Reprinted in New Studies in Philosophy, Politics, Economics and the History of Ideas Chicago: University of Chicago Press, 1978.

Hayek, F A. (1973) Law, Legislation and Liberty: Rules and Order, vol. 1 Chicago: University of Chicago Press.

Hayek, F. A. (1976) Law, Legislation and Liberty: The Mirage of Social Justice, vol. 2 Chicago: University of Chicago Press.

Hayek, F. A. (1978) "Competition as a Discovery Procedure." In New Studies in Philosophy, Politics, Economics and the History of Ideas Chicago: University of Chicago Press.

Hayek, F. A. (1988) The Fatal Conceit Chicago: University of Chicago Press.

Heiner, R. (1983) "The Origin of Predictable Behavior." American Economic Review 73: $560-95$.

Hempel, C. G. and Oppenheim, P. (1965) "Studies in the Logic of Explanation." In C. G. Hempel, Aspects of Scientific Explanation Glencoe, Ill.: Free Press.

Hey, J. D. (1981) Economics in Disequilibrium New York: New York University Press.

Hicks, J. (1935) "A Suggestion for Simplifying the Theory of Money." Economica n.s. 2: $1-19$.

Hicks, J. R. (1965) Capital Growth Oxford: Oxford University Press.

Hicks, J. R. (1967) “The Hayek Story.” In Critical Essays in Monetary Theory Oxford: Clarendon Press.

Hicks, J. R. (1974) The Crisis in Keynesian Economics New York: Basic Books.

Hicks, J. R. (1976) "Some Questions of Time in Economics." In A. M. Tan, F. M. Westfield and J. S. Worley (eds.) Evolution, Welfare, and Time in Economics Lexington, Mass.: Lexington Books, D. C. Heath \& Co.

High, J. (1986). "Equilibration and Disequilibration in the Market Process." In Israel M. Kirzner (ed.) Subjectivism, Intelligibility and Economic Understanding: Essays in Honor of Ludwig Lachmann New York: NYU Press.

Hood, W. C. (1948) "Some Aspects of the Treatment of Time in Economic Theory." Canadian Journal of Economics and Political Science 14: 453-68. 
Horwitz, S. (1992) Monetary Evolution, Free Banking and Economic Order Boulder: Westview Press.

Horwitz, S. (1993) "Spontaneity and Design in the Evolution of Institutions." Journal des Economistes et des Etudes Humaines 4: 571-88.

Horwitz, S. (1994) "Subjectivism." In P. J. Boettke (ed.) The Elgar Companion to Austrian Economics Aldershot, England: Edward Elgar.

Howard, R. A. (1971) Dynamic Probabilistic Systems, 2 vols New York: John Wiley.

Hurwicz, L. (1973) "The Design of Mechanisms for Resource Allocation." American Economic Review, Papers and Proceedings 63: 1-30.

Husserl, E. (1964) The Phenomenology of Internal Time-Consciousness. Trans. J. S. Churchill. Bloomington: University of Indiana Press.

Ikeda, S. (1990) "Market-Process Theory and 'Dynamic' Theories of the Market." Southern Economic Journal 57: 75-92.

Ikeda, S. (1997) Dynamics of the Mixed Economy: Toward a Theory of Interventionism London: Routledge.

James, W. (1890) The Principles of Psychology, vol. 1 New York: Henry Holt \& Company.

Jevons, W. S. (1970 [1871]) The Theory of Political Economy (ed.) R. D. C. Black. New York: Penguin Books.

Jones, R. (1976) "The Origin and Development of Media of Exchange." Journal of Political Economy 84: 757-75.

Kaldor, N. (1934) "A Classification Note on the Determinateness of Equilibrium." Review of Economic Studies 1: 122-36.

Kessel, R. A. and Alchian, A. A. (1962) "Effects of Inflation." Journal of Political Economy 70: 521-37. Reprinted in Economic Forces at Work: Selected Works by Armen A. Alchian Indianapolis: Liberty Press, 1977.

Keynes, J. M. (1964 [1936]) The General Theory of Employment, Interest, and Money New York: Harcourt, Brace \& World.

Keynes, J. M. (1973) Collected Writings XIV (ed.) D. Moggridge New York: St. Martin's Press.

Kirzner, I. M (1966) An Essay on Capital New York: Augustus M. Kelly.

Kirzner, I. M. (1973) Competition and Entrepreneurship Chicago: University of Chicago Press.

Kirzner, I. M. (1976) "Ludwig von Mises and the Theory of Capital and Interest." In L. S. Moss (ed.) The Economics of Ludwig von Mises Kansas City: Sheed \& Ward.

Kirzner, I. M. (1976b) “Equilibrium versus Market Process.” In E. G. Dolan (ed.) The Foundations of Modern Austrian Economics Kansas City: Sheed \& Ward.

Kirzner, I. M. (1979a) Perception, Opportunity, and Profit Chicago: University of Chicago Press.

Kirzner, I. M. (1982) “Uncertainty, Discovery, and Human Action.” In I. M. Kirzner (ed.) Method, Process, and Austrian Economics: Essays in Honor of Ludwig von Mises Lexington, Mass.: Lexington Books, D. C. Heath \& Co.

Kirzner, I. M. (1984) "Prices, the Communication of Knowledge and the Discovery Process." Unpublished manuscript.

Kirzner I. M. (1992) "Market Process Theory: In Defence of the Austrian Middle Ground." In The Meaning of Market Process: Essays in the Development of Modern Austrian Economics London and New York: Routledge.

Klein, B. (1975) "Our New Monetary Standard: The Measurement and Effects of Price Uncertainty, 1880-1973.” Economic Inquiry 13: 461-84. 
Klein, B. H. (1977) Dynamic Economics Cambridge, Mass.: Harvard University Press.

Knight, F. H. (1934) "Capital, Time, and the Interest Rate." Economica n.s. 1: 257-86.

Knight, F. H. (1946) "Capital and Interest." Encyclopedia Brittanica (14th edn) 4: 799-801. Reprinted in American Economic Association, Readings in the Theory of Income Distribution Philadelphia: Blakiston.

Knight, F. H. (1960 [1937]) "Unemployment: And Mr Keynes's Revolution in Economic Theory." In H. Hazlitt (ed.) The Critics of Keynesian Economics New Rochelle, New York: Arlington House.

Knight, F. H. (1971 [1921]) Risk, Uncertainty, and Profit Chicago: University of Chicago Press.

Kolko, G. (1967) The Triumph of Conservatism: A Reinterpretation of American History, 1900-1916 Chicago: Quadrangle.

Koppl, R. and Langlois, R. (1994) "When Do Ideas Matter? A Study in the Natural Selection of Social Games." In P. Boettke and M. Rizzo (eds.) Advances in Austrian Economics, vol. 1 Greenwich, CT: JAI Press.

Koppl, R. and Yeager, L. (1994) "Big Players and the Russian Ruble: Lessons from the Nineteenth Century." Unpublished manuscript at Fairleigh Dickinson University and Auburn University.

Kornai, J. (1971) Anti-Equilibrium: An Economic Systems Theory and the Tasks of Research Amsterdam: North-Holland.

Kornai, J. (1992) The Socialist System: The Political Economy of Communism Princeton: Princeton University Press.

Kuhn, T. S. (1970) The Structure of Scientific Revolutions (2nd edn) Chicago: University of Chicago Press.

Lachmann, L. M. (1943) "The Role of Expectations in Economics as a Social Science." Economica n.s. 10: 12-23. Reprinted in Walter E. Grinder (ed.) Capital, Expectations, and the Market Process Kansas City: Sheed, Andrews \& McMeel.

Lachmann, L. M. (1956) Capital and Its Structure London: G. Bell \& Sons.

Lachmann, L. M. (1959) "Professor Shackle and the Economic Significance of Time." Metroeconomica 11: 64-73.

Lachmann, L. M. (1969) "Methodological Individualism and the Market Process." In E. Streissler (ed.) Roads to Freedom: Essays in Honor of Friedrich von Hayek London: Routledge \& Kegan Paul.

Lachmann, L. M. (1971) The Legacy of Max Weber Berkeley, Cal.: Glendessary Press.

Lachmann, L. M. (1973) Macro-Economic Thinking and the Market Economy London: Institute of Economic Affairs, Hobart Paper no. 56.

Lachmann, L. M. (1976) "On the Central Concept of Austrian Economics: Market Process.” In E. G. Dolan (ed.) The Foundations of Modern Austrian Economics Kansas City: Sheed \& Ward.

Lachmann, L. M. (1977) "Ludwig von Mises and the Market Process." In Walter Grinder (ed.) Capital, Expectations and the Market Process Kansas City: Sheed, Andrews \& McMeel.

Lachmann, L. M. (1978) "An Austrian Stocktaking: Unsettled Questions and Tentative Answers." In L. M. Spadaro (ed.) New Directions in Austrian Economics Kansas City: Sheed, Andrews \& McMeel. 
Lachmann, L. M. (1984) "Economic Theory in Tempestuous Season." Trans. C. Dorfschmid. Unpublished (in English) manuscript, New York University.

Lachmann, L. M. (1986) The Market as an Economic Process Oxford: Basil Blackwell.

Lakatos, I. (1970) "Falsification and the Methodology of Scientific Research Programmes." In I. Lakatos and A. Musgrave (eds.) Criticism and the Growth of Knowledge Cambridge: Cambridge University Press.

Lancaster, K. J. (1966) "A New Approach to Consumer Theory." Journal of Political Economy 74: 132-57.

Langlois, R. N. (1982a) "Economics as a Process: Notes on the 'New Institutional Economics." C. V. Starr Center for Applied Economics Working Paper no. 82-21 New York University.

Langlois, R. N. (1982b) "Subjective Probability and Subjective Economics." Unpublished paper, New York University.

Langlois, R. N. (1984) "Internal Organization in a Dynamic Context." In M. Jasawalla and H. Ebenfield (eds.) Communication and Information Economics: New Perspectives Amsterdam: North-Holland.

Langlois, R. N. (1992) "Transaction-Cost Economics in Real Time." Industrial and Corporate Change 1: 99-127.

Langlois, R. N. and Koppl R. (1984) "Fritz Machlup and Marginalism: A Reevaluation." Unpublished manuscript.

Lavoie, D. C. (1985) Rivalry and Central Planning: The Socialist Calculation Debate Reconsidered Cambridge: Cambridge University Press.

Lawson, T. (1994a) "Critical Realism and the Analysis of Choice, Explanation and Change.” In P. Boettke and M. Rizzo (eds.) Advances in Austrian Economics, vol. 1 Greenwich, CT: JAI Press.

Lawson, T. (1994b) "The Nature of Post Keynesianism and Its Links to Other Traditions: A Realist Perspective." Journal of Post Keynesian Economics 16: 503-38.

Lawson, T. (1994c) "Realism, Philosophical.” In G. Hodgson, W. Samuels and M. Tool (eds.) The Elgar Companion to Evolutionary and Institutional Economics, vol. 2 Aldershot, England: Edward Elgar.

Leijonhufvud, A. (1968) On Keynesian Economics and the Economics of Keynes New York: Oxford University Press.

Leijonhufvud, A. (1981a) "The Wicksell Connection: Variations on a Theme." In Information and Coordination Oxford: Oxford University Press.

Leijonhufvud, A. (1981b) "Effective Demand Failures." In Information and Coordination Oxford: Oxford University Press.

Leijonhufvud, A. (1983a) "What Would Keynes Have Thought of Rational Expectations?" UCLA Department of Economics Discussion Paper no. 299 Los Angeles: UCLA.

Leijonhufvud, A. (1983b) "Rational Expectations and Monetary Institutions." UCLA Department of Economics Discussion Paper no. 302 Los Angeles: UCLA.

Leoni, B. (1961) Freedom and the Law Princeton, NJ: D. Van Nostrand.

Letwin, W. (1965) Law and Economic Policy in America: The Evolution of the Sherman Antitrust Act New York: Random House.

Lewin, P. (1982) "Perspectives on the Costs of Inflation." Southern Economic Journal 48: $627-41$. 
Lindahl, E. (1939) Studies in the Theory of Money and Capital London: George Allen \& Unwin.

Littlechild, S. C. (1977) Change Rules, O.K.? Birmingham: University of Birmingham.

Littlechild, S. C. (1979) The Fallacy of the Mixed Economy San Francisco: Cato Institute.

Loasby, B. J. (1976) Choice, Complexity, and Ignorance Cambridge: Cambridge University Press.

Loasby, B. J. (1991) Equilibrium and Evolution Manchester: Manchester University Press.

Lucas, R. E. Jr. (1973) "Some International Evidence on Output Inflation Tradeoffs." American Economic Review 63: 326-34.

Lucas, R. E. Jr. (1975) "An Equilibrium Model of the Business Cycle.” Journal of Political Economy 83: 1113-44.

Lucas, R. E. Jr. (1977) "Understanding Business Cycles.” In K. Brunner and A. H. Meltzer (eds.) Stabilization of the Domestic and International Economy Amsterdam: North-Holland.

Machlup, F. (1958) "Equilibrium and Disequilibrium: Misplaced Concreteness and Disguised Politics." Economic Journal 68: 1-24. Reprinted in Essays in Economic Semantics New York: W. W. Norton, 1967. Also reprinted in International Payments, Debts, and Gold (2nd edn) New York: New York University Press, 1976.

Machlup, F. (1978a) "The Ideal Type: A Bad Name for a Good Construct." In Methodology of Economics and Other Social Sciences New York: Academic Press.

Machlup, F. (1978b) "Spiro Latsis on Situational Determinism." In Methodology of Economics and Other Social Sciences New York: Academic Press.

Maddock, R. and Carter, M. (1982) "A Child's Guide to Rational Expectations." Journal of Economic Literature 20: 39-51.

Mäki, U. (1990) "Scientific Realism and Austrian Explanation." In Review of Political Economy 2: 310-44.

Marshall, A. (1961) Principles of Economics (9th edn) London: Macmillan for the Royal Economic Society.

Mayer, H. (1994 [1932]) "The Cognitive Value of Functional Price Theory." In Israel M. Kirzner (ed.) Classics in Austrian Economics, vol. 2 The Interwar Period London: Pickering and Chatto.

Menger, C. (1892) "On the Origin of Money." Trans. C. A. Foley. Economic Journal 2: $238-55$.

Menger, C. (1963 [1883]) Problems of Economics and Sociology (ed.) L. Schneider and trans. F. J. Nock. Urbana, Ill.: University of Illinois Press.

Menger, C. (1981 [1871]) Principles of Economics (ed.) J. Dingwall and trans. B. F. Hoselitz. New York: New York University Press.

Mill, J. S. (1973 [1848]) Principles of Political Economy, with Some of Their Applications to Social Philosophy New York: Augustus M. Kelley.

Mirowski, P. (1989) More Heat than Light Cambridge: Cambridge University Press.

Mises, L. v. (1953 [1912]) The Theory of Money and Credit Trans. H. E. Batson. New Haven: Yale University Press.

Mises, L. v. (1966) Human Action: A Treatise on Economics (3rd edn) New York: Henry Regnery \& Co. 
Morgenstern, O. (1935) "Perfect Foresight and Economic Equilibrium." Zeitschrift für Nationalökonomie 6 (part 3). Trans. F. H. Knight in A. Schotter (ed.) Selected Writings of Oskar Morgenstern New York: New York University Press, 1976.

Morgenstern, O. (1972) "Descriptive, Predictive, and Normative Theory." Kyklos 25: 699-714.

Muth, J. F. (1961) "Rational Expectations and the Theory of Price Movements." Econometrica 29: 315-35.

Myrdal, G. (1939) Monetary Equilibrium London: William Hodge.

Nelson, R. R. and Winter, S. G. (1982) An Evolutionary Theory of Economic Change Cambridge, Mass.: Harvard University Press, The Belknap Press.

O'Connor, D. J. (1957) "Determinism and Predictability." British Journal for the Philosophy of Science 7: 310-15.

O'Driscoll, G. P. Jr. (1977) Economics as a Coordination Problem: The Contributions of Friedrich A. Hayek Kansas City: Sheed, Andrews \& McMeel.

O'Driscoll, G. P. Jr. (1979) "Rational Expectations, Politics, and Stagflation." In M. J. Rizzo (ed.) Time, Uncertainty, and Disequilibrium Lexington, Mass.: Lexington Books, D. C. Heath and Co.

O'Driscoll, G. P. Jr. (1980) "Justice, Efficiency, and the Economic Analysis of Law: Comment on Fried.” Journal of Legal Studies 9: 355-66.

O’Driscoll, G. P. Jr. (1981) “Knowing, Expecting, and Theorizing.” C. V. Starr Center for Applied Economics Working Paper no. 81-82, New York University.

O’Driscoll, G. P. Jr. (1982) “Monopoly in Theory and Practice.” In I. M. Kirzner (ed.) Method, Process, and Austrian Economics: Essays in Honor of Ludwig von Mises Lexington, Mass.: Lexington Books, D. C. Heath \& Co.

O’Driscoll, G. P. Jr. (1983) “A Free-Market Money: Comment on Yeager.” The Cato Journal 3: 327-33.

O’Driscoll, G. P. Jr. (1984a) “Expectations and Monetary Regimes.” Federal Reserve Bank of Dallas Economic Review September 1984.

O'Driscoll, G. P. Jr. (1984b) "Carl Menger and Modern Economics.” Unpublished manuscript.

O’Driscoll, G. P. Jr. (1989) “A Tribute to F. A. Hayek.” The Cato Journal 9: 345-52.

O'Driscoll, G. P. Jr. and Shenoy, S. R. (1976) "Inflation, Recession, and Stagflation." In E. G. Dolan (ed.) The Foundations of Modern Austrian Economics Kansas City: Sheed \& Ward.

O’Hear, A. (1980) Karl Popper London: Routledge \& Kegan Paul.

Patinkin, D. (1965) Money, Interest, and Prices (2nd edn) New York: Harper \& Row.

Peltzman, S. (1976) “Toward a More General Theory of Regulation." Journal of Law and Economics 19: 211-40.

Plant, A. (1934) "The Economic Theory Concerning Patents for Inventions." Economica n.s. 1: 30-51.

Polanyi, M. (1962) Personal Knowledge: Towards a Post-Critical Philosophy Chicago: University of Chicago Press.

Poole, W. (1976) "Rational Expectations in the Macro Model." Brookings Papers on Economic Activity 2: 463-514.

Popper, K. R. (1950) "Indeterminism in Quantum Physics and in Classical Physics." British Journal for the Philosophy of Science 1: 117-33, 173-95.

Popper, K. R. (1959) "The Propensity Interpretation of Probability." British Journal for the Philosophy of Science 10: 25-42. 
Popper, K. R. (1964) The Poverty of Historicism New York: Harper Torchbooks.

Popper, K. R. (1965 [1934]) The Logic of Scientific Discovery New York: Harper Torchbooks, Harper \& Row.

Popper, K. R. (1979a) "Of Clouds and Clocks." In Objective Knowledge Oxford: Oxford University Press.

Popper, K. R. (1979b) “On the Theory of the Objective Mind." In Objective Knowledge Oxford: Clarendon Press.

Posner, R. A. (1975) "The Social Costs of Monopoly and Regulation." Journal of Political Economy 83: 807-27.

Posner, R. A. (1977) Economic Analysis of Law Boston: Little, Brown.

Posner, R. A. (1979) "The Chicago School of Antitrust Analysis." University of Pennsylvania Law Review 127: 925-48.

Prigogine, I. and Stengers, I. (1984) Order Out of Chaos New York: Bantam Books.

Prychitko, D. (1991) Marxism and Workers' Self-Management: The Essential Tension New York: Greenwood Press.

Prychitko, D. L. (1993a) “After Davidson, Who Needs the Austrians?" Critical Review 7: $371-80$.

Prychitko, D. L. (1993b) "Formalism in Austrian-School Welfare Economics: Another Pretense of Knowledge?" Critical Review 7: 567-92.

Pye, R. (1978) "A Formal Decision-Theoretical Approach to Flexibility and Robustness." Journal of the Operational Research Society 29: 215-27.

Radner, R. (1970) "Problems in the Theory of Markets under Uncertainty." American Economic Review, Papers and Proceedings 60: 454-60. Reprinted in R. E. Neel (ed.) Readings in Price Theory Cincinnati, Ohio: South-Western Publishing, 1973.

Radner, R. (1975) “A Behavioral Model of Cost Reduction.” Bell Journal of Economics 6: 195-215.

Rawls, J. (1963) Constitutional Liberty and the Concept of Justice New York: Nomos, New York University Press.

Reder, M. (1982) "Chicago Economics: Permanence and Change.” Journal of Economic Literature 20: 1-38.

Richardson, G. B. (1960) Information and Investment Oxford: Oxford University Press.

Rizzo, M. J.(1979) “Disequilibrium and All That.”In M. J. Rizzo(ed.) Time, Uncertainty, and Disequilibrium Lexington, Mass.: Lexington Books, D. C. Heath \& Co.

Rizzo, M. J. (1980a) "Law amid Flux: The Economics of Negligence and Strict Liability in Tort." Journal of Legal Studies 9: 291-318.

Rizzo, M. J. (1980b) "The Mirage of Efficiency.” Hofstra Law Review 8: 641-58.

Rizzo, M. J. (1981) "The Imputation Theory of Proximate Cause: An Economic Framework." Georgia Law Review 15: 1007-38.

Rizzo, M. J. (1984) "Re-examination of the Rules against Horizontal Collusive Arrangements: An Outline." Unpublished manuscript, New York University.

Rizzo, M. J. (1985) "Rules versus Cost-Benefit Analysis in the Common Law." Cato Journal 4: 865-84.

Rizzo, M. J. (1990) "Hayek's Four Tendencies towards Equilibrium." Cultural Dynamics 3: 12-31.

Rizzo, M. J. (1992) "Austrian Economics for the Twenty-First Century." In B. J. Caldwell and S. Boehm (eds.) Austrian Economics: Tensions and New Directions Boston: Kluwer.

Rizzo, M. J. and Arnold, F. S. (1980) "Causal Apportionment in the Law of Torts: An Economic Theory.” Columbia Law Review 80: 1399-429. 
Robbins, L. (1934) The Great Depression London: Macmillan.

Robertson, D. H. (1940) "Industrial Fluctuations and the Natural Rate of Interest." In Essays in Monetary Theory London: P. S. King \& Son.

Robertson, D. H. (1949 [1926]) Banking Policy and the Price Level New York: Augustus M. Kelley.

Robinson, J. (1971 [1953-54]) "The Production Function and the Theory of Capital." In G. C. Harcourt and N. F. Laing (eds.) Capital and Growth Middlesex, England: Penguin.

Robinson, J. (1977) "What Are the Questions?" Journal of Economic Literature 15: 1318-39.

Rolph, E. R. (1980) "On the Austrian Theory of Capital: A Comment.” Economic Inquiry 18: 501-3.

Rosenberg, N. (1969) "The Direction of Technological Change: Inducement Mechanisms and Focusing Devices." Economic Development and Cultural Change 18: 1-24.

Rothbard, M. N. (1963) America's Great Depression. Princeton, New Jersey: D. Van Nostrand.

Rothbard, M. N. (1970 [1962]) Man, Economy, and State, 2 vols Los Angeles: Nash.

Ryle, G. (1949) "Knowing How and Knowing That." In The Concept of Mind London: Hutchinson's University Library.

Samuelson, P. A. (1966) "A Summing Up." Quarterly Journal of Economics 80: 568-83.

Savage, L. J. (1972) The Foundations of Statistics (2nd edn) New York: Dover Publications.

Schick, F. (1979) "Self-Knowledge, Uncertainty, and Choice." British Journal for the Philosophy of Science 30: 235-52.

Schotter, A. (1981) The Theory of Economic Institutions Cambridge: Cambridge University Press.

Schumpeter, J. A. (1934) The Theory of Economic Development Trans. R. Opie. Cambridge, Mass.: Harvard University Press.

Schumpeter, J. A. (1954) History of Economic Analysis (ed.) E. B. Schumpeter from manuscript. Oxford: Oxford University Press.

Schutz, A. (1945) "On Multiple Realities." Philosophy and Phenomenological Research 5: 533-76. Reprinted in Maurice Natanson (ed.) Collected Papers I: The Problem of Social Reality The Hague: Martinus Nijhoff, 1964.

Schutz, A. (1953) "Common-Sense and Scientific Interpretation of Human Action." Philosophy and Phenomenological Research. 14: 1-38. Reprinted in Maurice Natanson (ed.) Philosophy of the Social Sciences New York: Random House, 1963. Also reprinted in Maurice Natanson (ed.) Collected Papers I: The Problem of Social Reality The Hague: Martinus Nijhoff, 1964.

Schutz, A. (1954) "Concept and Theory Formation in the Social Sciences." Journal of Philosophy 51: 257-73. Reprinted in Maurice Natanson (ed.) Philosophy of the Social Sciences New York: Random House, 1963. Also reprinted in Maurice Natanson (ed.) Collected Papers I: The Problem of Social Reality The Hague: Martinus Nijhoff, 1964.

Schutz, A. (1967) The Phenomenology of the Social World Trans. George Walsh and Frederick Lehnert. Evanston, Ill.: Northwestern University Press.

Schutz, A. and Luckmann, T. (1973) The Structures of the Life World Evanston, Ill.: Northwestern University Press.

Selgin, G. A. (1988) The Theory of Free Banking Totowa, NJ: Rowman and Littlefield. 
Selgin, G. A. and White, L. H. (1994) "How Would the Invisible Hand Handle Money?" Journal of Economic Literature 32: 1718-49.

Shackle, G. L. S. (1958) Time in Economics Amsterdam: North-Holland.

Shackle, G. L. S. (1967) The Years of High Theory Cambridge: Cambridge University Press.

Shackle, G. L. S. (1969) Decision, Order, and Time in Human Affairs (2nd edn) Cambridge: Cambridge University Press.

Shackle, G. L. S. (1970) Expectation, Enterprise and Profit: The Theory of the Firm Chicago: Aldine.

Shackle, G. L. S. (1972) Epistemics and Economics Cambridge: Cambridge University Press.

Shackle, G. L. S. (1979) "Imagination, Formalism, and Choice" In Mario J. Rizzo (ed.) Time, Uncertainty, and Disequilibrium Lexington, Mass.: Lexington Book, D. C. Heath and Co.

Short, E. D. and O’Driscoll, G. P. Jr. (1983) "Deposit Insurance and Financial Stability." Business Forum Summer: 10-13.

Smith, A. (1937 [1776]) An Inquiry into the Nature and Causes of the Wealth of Nations (ed.) E. Cannan New York: Modern Library.

Snowdon, B., Vane, H. and Wynarczyk, P. (1994) A Modern Guide to Macroeconomics Aldershot, England: Edward Elgar.

Sowell, T. (1980) Knowledge and Decisions New York: Basic Books.

Spencer, H. (1888) A System of Synthetic Philosophy, vol. 1: First Principles (4th edn) New York: D. Appleton \& Company.

Sraffa, P. (1960) The Production of Commodities by Means of Commodities: A Prelude to a Critique of Economic Theory Cambridge: Cambridge University Press.

Starbuck, W. H. and Milliken, F. J. (1988) "Executives' Perceptual Filters: What They Notice and How They Make Sense." In D. Hambrick (ed.) The Executive Effect: Concepts and Methods for Studying Top Managers Greenwich, CT: JAI Press.

Stigler, G. J. (1966) The Theory of Price (3rd edn) New York: Macmillan \& Co.

Stigler, G. J. (1982) "Economists and Public Policy." Regulation 6: 13-17.

Stigler, G. J. and Becker, G. S. (1977) "De Gustibus Non Est Disputandum.” American Economic Review 67: 76-90.

Streissler, E. and Weber, W. (1973) "The Mengerian Tradition." In J. R. Hicks and W. Weber (eds.) Carl Menger and the Austrian School of Economics Oxford: Clarendon Press.

Thirlby, G. F (1973) “Economists' Cost Rules and Equilibrium Theory.” In J. Buchanan and G. F. Thirlby (eds.) LSE Essays on Cost London: Weidenfeld and Nicolson.

Tullock, G. (1967) "The Welfare Costs of Tariffs, Monopolies, and Theft." Western Economic Journal 5: 224-32.

Vaughn, K. I. (1994) Austrian Economics in America: The Migration of a Tradition Cambridge: Cambridge University Press.

von Neumann, J. and Morgenstern, O. (1947) Theory of Games and Economic Behavior Princeton: Princeton University Press.

Wagner, R. E. (1979) "Comment: Politics, Monetary Control, and Economic Performance." In M. J. Rizzo (ed.) Time, Uncertainty, and Disequilibrium Lexington, Mass.: Lexington Books, D. C. Heath and Co.

Wainhouse, C. W. (1982) "Hayek's Theory of the Trade Cycle: The Evidence from the Time Series." PhD dissertation, New York University. 
Walsh, V. and Gram, H. (1980) Classical and Neoclassical Theories of General Equilibrium: Historical Origins and Mathematical Structure New York: Oxford University Press.

Weintraub, E. R. (1979) Microfoundations: The Compatibility of Microeconomics and Macroeconomics Cambridge: Cambridge University Press.

White, L. H. (1978) "Entrepreneurial Price Adjustment." Unpublished manuscript, New York University.

White, L. H. (1984) Free Banking in Britain Cambridge: Cambridge University Press.

White, L. H. (1989) Competition and Currency: Essays on Free Banking and Money New York: New York University Press.

Whitehead, A. N. (1939) An Introduction to Mathematics New York: Henry Holt.

Whitehead, A. N. (1961) “Time.” In R. N. Anshen (ed.) Alfred North Whitehead: His Reflections on Man and Nature New York: Harper \& Brothers.

Wicksell, K. (1965 [1898]) Interest and Prices: A Study of the Causes Regulating the Value of Money Trans. R. F. Kahn. New York: Augustus M. Kelley.

Wicksteed, P. H. (1967 [1910]) The Common Sense of Political Economy, vol. 1 New York: Augustus M. Kelly.

Winter, S. (1971) "Satisficing, Selection, and the Innovating Remnant." Quarterly Journal of Economics 85: 237-61.

Witt, U. (1992) "Turning Austrian Economics into an Evolutionary Theory." In B. J. Caldwell and S. Boehm (eds.) Austrian Economics: Tensions and New Directions Boston: Kluwer Academic Publishers.

Yeager, L. B. (1979) “Capital Paradoxes and the Concept of Waiting.” In M. J. Rizzo (ed.) Time, Uncertainty, and Disequilibrium Lexington, Mass.: Lexington Books, D. C. Heath \& Co.

Yolton, J. W. (1959) "Explanation.” British Journal for the Philosophy of Science 10: 194-208. 